\title{
Deleted in Esophageal Cancer 1
}

National Cancer Institute

\section{Source}

National Cancer Institute. Deleted in Esophageal Cancer 1. NCI Thesaurus. Code C26215.

Deleted in esophageal cancer 1 (70 aa, $8 \mathrm{kDa}$ ) is encoded by the human DEC1 gene.

This protein may be involved in tumor suppression. 